\title{
TECHNICAL PROGRESS REPORT
}

\author{
APRIL - JUNE 1989
}

For:

\begin{tabular}{c:cc} 
U.S. Department of Energy & - & $\vdots$ \\
Pittsburgh Energy Technology Center & $\cdots$ & $\vdots$ \\
\hline & - &
\end{tabular}

Under:

DOE Contract No. DE-AC22-87PC79654 Development of a Retrofit Coal Comibustor for Industrial Applications (Phase II)

By:

MANUFACTURING AND TECHNOLOGY CONVERSION INTERNATIONAL, INC.

P.O. Box 21, Columbia, Maryland 21045-0021

July 1989

\section{MASTER}




\section{PREFACE}

A detailed description of the background, technology and application for the development of a retrofit coal combustor for industrial applications was provided in the first quarterly report for the period January 1987 March 1987. In June of 1988, DOE Contract No. DE-AC22-87PC79654 was modified with the addition of a new task, as a Phase IA, to bridge the gap between Phase I and II of the program. That material is omitted from this report. Phase II was initiated on April 3, 1989. This report covers the period April 3, 1989 through July 9, 1989. It also includes a revised Section 1.2, Phase II Task Descriptions, that provides the task structure for the Phase II of the development effort. In addition, this quarterly report includes a section on the Phase IA slurry injection testing effort which had not been previousiy reported.

The development of the pilot-scale unit was initiated in early April and Task 1 activities for fabrication, test and evaluation were held in abeyance until the Task. 2 effort for technical and laboratory-scale support had sufficiently advanced to the point where it could provide confidence in the ability to design and fabricate the larger unit so that it perform as intended. In addition, this Task 2 effort included the upgrading, enhancement, and testing of the empirical computer code developed in Phase I. System components such as the sorbent injection and collection system were installed, tested, and evaluated using the Phase IA integrated system as a test bed to provide information useful in the design and fabrication of the pilot-scale unit. During this period, the Task 1 activities consisted of additional site preparation that was carried out for the installation of the pilot-scale system. The improvements consisted of moving and rerouting the intake and exhaust blowers and related ducting, increasing ceiling height and the design of a refractory sleeve for connecting the decoupler to the boiler.

\section{DISCLAIMER}

\begin{abstract}
This report was prepared as an account of work sponsored by an agency of the United States Government. Neither the United States Government nor any agency thureof, nor any of their employees, makes any warranty, express or implied, or assumes any legal liability or responsibility for the accuracy, completeness, or usefulness of any information, apparatus, product, or process disclosed, or represents that its use would not infringe privately owned rights. Reference herein to any specific commercial product, process, or service by trade name, trademark, manufacturer, or otherwise does not necessarily constitute or imply its endorsement, recommendation, or favoring by the United States Government or any agency thereof. The views and opinions of authors expressed herein do not necessarily state or reflect those of the United States Government or any agency thereof.
\end{abstract}

ERBT-24Q.PRE 


\section{TABLE OF CONTENTS}

Page

1.0 PROGRAM DESCRIPTION AND WORK STATUS . . . . . . . . . . . . 1

1.1 PROGRAM DESCRIPTION ................... 1

1.2 TASK DESCRIPTIONS - PHASE II, PILOT-SCALE

COMBUSTOR DEVELOPMENT . . . . . . . . . . . . . . . 3

1.2.1 Task 1: Fabrication of the Pilot-Scale Combustor ........... 3

1.2.2 Task 2: Technical and Laboratory-
Scale Support . . . . . . . . . . . 5

1.2.3 Task 3: Design of a Retrofit Combustor
System for Field Demonstration......... 5

1.3 STATUS ........................ 6

2.0 TECHNICAL DISCUSSION OF WORK COMPLETED

DURING THE REPORTING PERIOD . . . . . . . . . . . . . . . 7

2.1 TASK 2: TECHNICAL AND LABORATORY-SCALE SUPPORT . . . . . 7

2.2 COAL-WATER SLURRY INJECTOR DESIGNS AND TEST

(Phase IA) . . . . . . . . . . . . . . . 13

3.0 PLANNED ACTIVITY FOR THE NEXT PERIOD . . . . . . . . . . . . 2 I 


\section{LIST OF FIGURES}

Page

FIGURE 1 PROGRAM LOGIC FOR THE DEVELOPMENT OF AN ADVANCED

PULSED-COAL COMBUSTOR FOR RETROFIT APPLICATIONS . . . . . 2

FIGURE 2 SCHEMATIC DIAGRAM OF LIME INJECTION/

COLLECTION UNIT INCORPORATED WITHIN TANDEM UNIT . . . . . 8

FIGURE 3 SCHEMATIC DIAGRAM OF LIME INJECTION AT POSITION (1) . . . 9

FIGURE 4 SCHEMATIC DIAGRAM OF LIME INJECTION AT POSITION (2) . . . 1 I

FIGURE 5 ATOMIZATION PATTERN . . . . . . . . . . . . . . . . 14

FIGURE 6 INJECTOR ASSEMBLY . . . . . . . . . . . . . . . . 16

FIGURE 7 VARIOUS DIVERGING DISCS . . . . . . . . . . . . . . 17

FIGURE 8 COMBUSTOR CONFIGURATION . . . . . . . . . . . . . 20

\section{LIST OF TABLES}

TABLE 1 SHAKEDOWN TESTS ................ 12

TABLE 2 PROXIMATE AND ULTIMATE AND SULFUR FROM ANALYSES FOR LOWER KITTANING COAL . . . . . . . . 12

TABLE 3 SORBENT INJECTION TEST MATRIX ........... 13 


\section{SECTION 1.0}

\section{PROGRAM DESCRIPTION AND WORK STATUS}

\subsection{PROGRAM DESCRIPTION}

The objective of Phase I of the program for the development of a retrofit pulse coal combustor for industrial applications was to design, fabricate, test and evaluate advanced chamber designs at the laboratory-scale utilizing several fuels (Task 1). The activities were structured to provide design criteria for scaling up to the pilot-scale level for the demonstration of a pulse combustor fired with coal-water mixtures for industrial boiler and process heater retrofit applications. The program logic is depicted in Figure 1.

The design data and information acquired during Task 1 of the initial phase was to develop scale-up design criteria for scaling the laboratoryscale design to pilot-scale including interface requirements for the field demonstration. The scale-up pilot unit design was to be sufficiently developed to allow fabrication of the unit for testing in the existing test facility upon DOE exercising its option for the follow-on activities of this program. These follow-on activities (Phase II) included the fabrication, test, and engineering evaluation of the pilot-scaie combustor as well as technical and laboratory test support activities for reducing the technical risks and costs of development at the pilot-scale. Based on the information, test, data and technical support activities, a retrofit combustor system was to be designed for field demonstration as shown on the left in Figure 1.

An additional effort - Phase IA - was added to the contract by modification A005. This modification added a Phase IA in place of the original Task 2 of Phase I activity. This interim phase consisted of three technical tasks that were described in previous quarterly reports. Phase II was initiated in April 1989. The task structure for the Phase II Statement of Work is now provided in Section 1.2. An additional task (Task 4) entitled "Management and Reporting" is not included in the following discussion. 


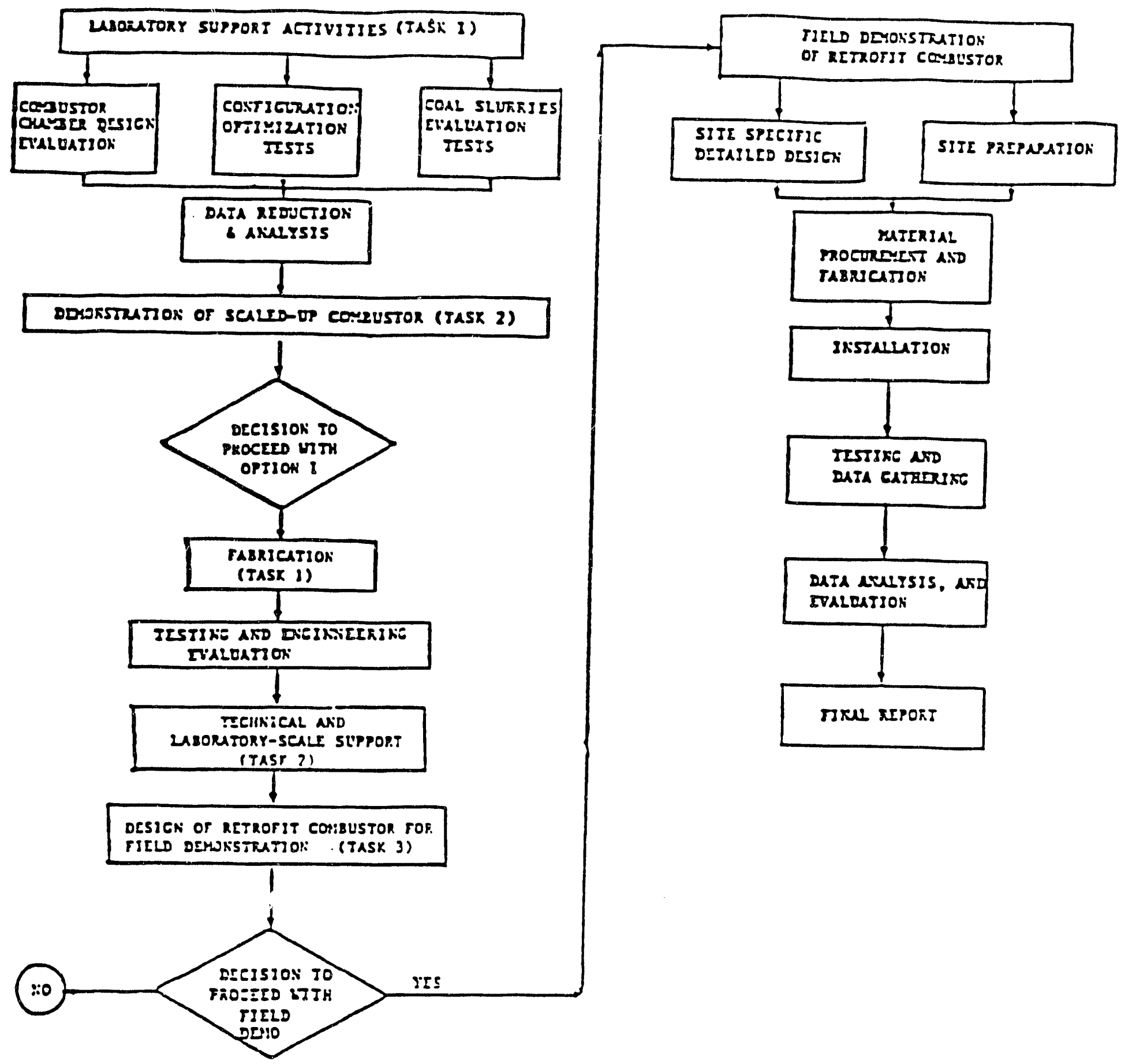

FIGURE 1: PROGRAM LOGIC FOR DEVELOPMENT OF A PULSE COAL COMBUSTOR FOR RETROFIT APPLICATIONS 


\subsection{TASK DESCRIPTIONS - PHASE II, PILOT-SCALE COMBUSTOR DEVELOPMENT}

\subsubsection{TASK 1: FABRICATION OF THE Pilot-SCALe Combustor}

The Contractor shall undertake a pilot-scale development and test activity which is aimed at the pilot-scale demonstration of a pulse coal combustor fired with dry, pulverized coal for industrial boiler and process heater retrofit applications. In conducting the pilot-scale demonstration, the Contractor shall undertake the following two subtasks:

\section{SUBTASK 1.1: PILOT-SCALE COMBUSTOR FABRICATION}

The scaled-up design, developed under Phase I, shall be fabricated and integrated to a boiler test facility and prepared for conducting the testing and engineering evaluations described below under Subtask 1.2.

In fabricating the scale-up combustor and integrating it in the test facility, the Contractor shall procure all the necessary materials, equipment, instrumentation and supplies and shall provide for all facility modifications for fuel and air supplies and sound-muffling provisions.

\section{SUBTASK 1.2: TESTING AND ENGINEERING EVALUATION}

The Contractor shall initially conduct tests of the pilot-scale pulse combustor with natural gas. This snall be followed by tests which employ dry, pulverized coal.

In implementing this task, the Contractor shall prepare a test plan (for each test fuel) detailing the combustor design, facility modifications and the planned sequence, procedures and test data acquisition for conducting the test activities. The test plan shall be supplied to the DOE Technical Program Monitor for review and approval.

Test activities shall include shakedown runs to establish stable performance and overall facility readiness. Mass and energy balance 
calculations shall also be undertaken by the Contractor to develop procedures and methods suitable for reliable determination of the combustion efficiency.

During each test run, the Contractor shall periodically record the following measurements:

- Fuel mass flow rate and combustor pressure wave intensity,

- Primary and secondary air flow rates (time average) and temperatures,

- Unburned carbon loss, and

- Flue gas analysis $\left(\mathrm{O}_{2}, \mathrm{CO}_{2}, \mathrm{CO}, \mathrm{SO}_{x}, \mathrm{NO}_{x}\right.$, etc.).

In addition, the following test data will be taken on an as-required basis:

- Flue gas analysis of the pulsating combustor's exit gas stream using analytical equipment to determine the level of unburned hydrocarbons, if any,

- Primary and secondary air flow rate vs. time,

- Pressure measurements (locations determined during testing),

- Chemical and size analyses of fuel feedstock, slag and fly ash, and

- Heat absorbed by the furnace, flue gas flow rate, and furnace exit temperature.

The Contractor shall reduce the test data and analyze and correlate the reduced data as a function of the combustor load. The pilot-scale data shall be compared with the integrated small industrial-scale pulse combustor data (Phase IA) to assess the effect of scale-up on the combustor performance.

The Contractor shall also employ the test results to undertake an assessment of the commercial retrofit applications to industrial boilers and process heaters. In addition, the Contractor shall document all the operating 
experience including maintenance-related experiences and shall employ such information in the assessment of the commercial application of the combustor technology.

\subsubsection{TASK 2: TECHNICAL AND LABORATORY-SCALE SUPPORT}

In support of the pilot-scale development and demonstration, defined in 1.4.1 above, the Contractor shall undertake technical evaluation and laboratory test activities to reduce the technical risks and associated costs of the combustor development at the pilot-scale.

This shall include engineering analysis of modifications contemplated for the pilot-scale system and laboratory-scale testing of such modifications or subsystems prior to incorporating them at the pilot-scale.

In supporting the pilot-scale combustor development, the Contractor shall employ and enhance the empirical computer code for combustor performance and scale-up analysis developed in Phase I and shall employ supplemental laboratory-scale tests to address technical issues resulting from the pilotscale development work.

\subsubsection{Task 3: Design of a Retrofit Combustor SYSTEM FOR FIELD DEMONSTRATION}

Based on the results of both Tasks 1 and 2 defined above, the Contractor shall formulate Prototype Systems Designs for two firing rates having a commercially viable opportunity in the small industrial boiler retrofit market. These systems will have firing rates of $15 \mathrm{MMBtu} / \mathrm{hr}$ and $25 \mathrm{MMBtu} / \mathrm{hr}$, with the primary fuel being dry coal and the secondary fuel being natural gas.

The designs shall be in accordance with all the applicable codes and according to the standard design practice employed in the design of boilers and fired heaters.

The design performance goal of the retrofit combustor shall be equal to or exceed the performance requirements articulated in PRDA RA22-86PC90259, issued by DOE/PETC, for the industrial boiler and process heater retrofit 
applications. The retrofit combustor system shall include fuel storage facilities, fuel feed subsystems, the retrofit combustor, ash removal subsystem, other particulate emission control devices, if any, and instrumentation suitable for field demonstration of performance and controls.

The Contractor shall prepare and deliver to DOE all drawings and specifications required for procurement, fabrication and field installation of the retrofit combustor systems.

The Contractor shall clearly designate drawings and related specifications proprietary as deemed appropriate, should the Contractor need to secure proprietary information protection for the material, under the applicable procurement regulation and contract provisions.

\subsection{STATUS}

The sorbent injection collection system was designed, fabricated and tested in the Phase IA integrated system to provide basic integration and operation information for the pilot-scale system. Preliminary designs for the 7.5 MMBtu/hr unit were also initiated utilizing the MTCI design code. Installation of the test bed for the Phase II pilot unit was also initiated. 
SECTION 2.0

\section{TECHNICAL DISCUSSION OF WORK COMPLETED \\ DURING THE REPORTING PERIOD}

The development of the pilot-scale unit was initiated in early April and Task 1 activities for fabrication, test and evaluation were held in abeyance until the Task 2 effort for technical and laboratory-scale support had sufficiently advanced to the point where it could provide confidence in the ability to design and fabricate the larger unit so that it perform as intended. In addition, this Task 2 effort included the upgrading, enhancement, and testing of the empirical computer code developed in Phase I. System components such as the sorbent injection and collection system were installed, tested, and evaluated using the Phase IA integrated system as a test bed to provide information useful in the design and fabrication of the pilot-scale unit. During this period, the Task 1 activities consisted of additional site preparation that was carried out for the installation of the pilot-scale system. The improvements consisted of moving and rerouting the intake and exhaust blowers and related ducting, increasing ceiling height and the design of a refractory sleeve for connecting the decoupler to the boiler.

\subsection{TASK 2: TECHNICAL AND LABORATORY-SCALE SUPPORT}

The fabrication and installation of the sorbent injection and collection system was completed during May and the system tested in the Phase IA integrated system.

A schematic diagram of sorbent injection/collection unit incorporated in the industrial tandem unit is provided in Figure 2. As shown in the figure, two limestone injection positions were chosen.

Position (1) is located at the connecting section between the cyclonic decoupler and the fire-tube boiler, as shown in Figure 3 . At this region the temperature of the gas is approximately $2200^{\circ} \mathrm{F}$, with tertiary air injection. 


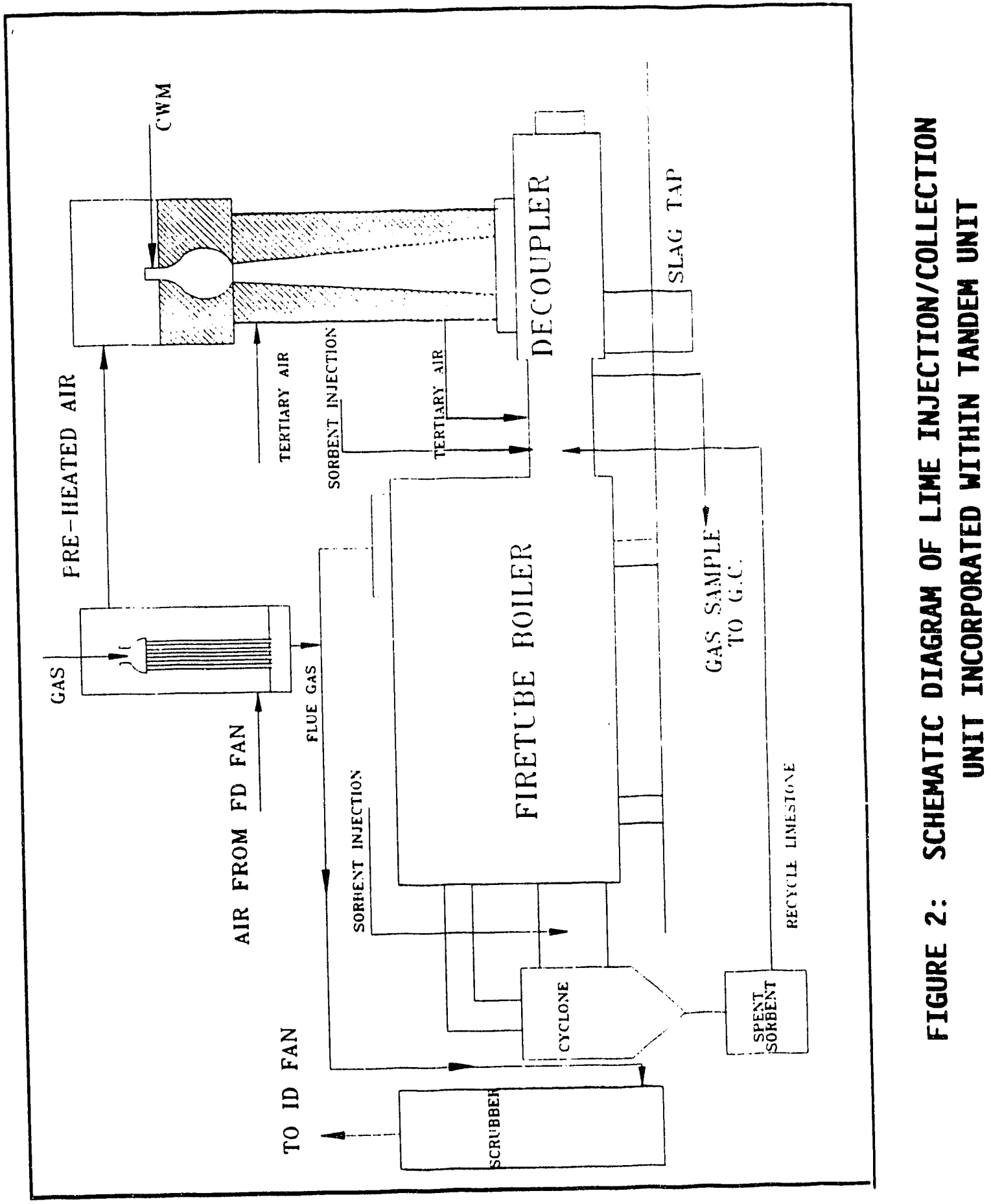




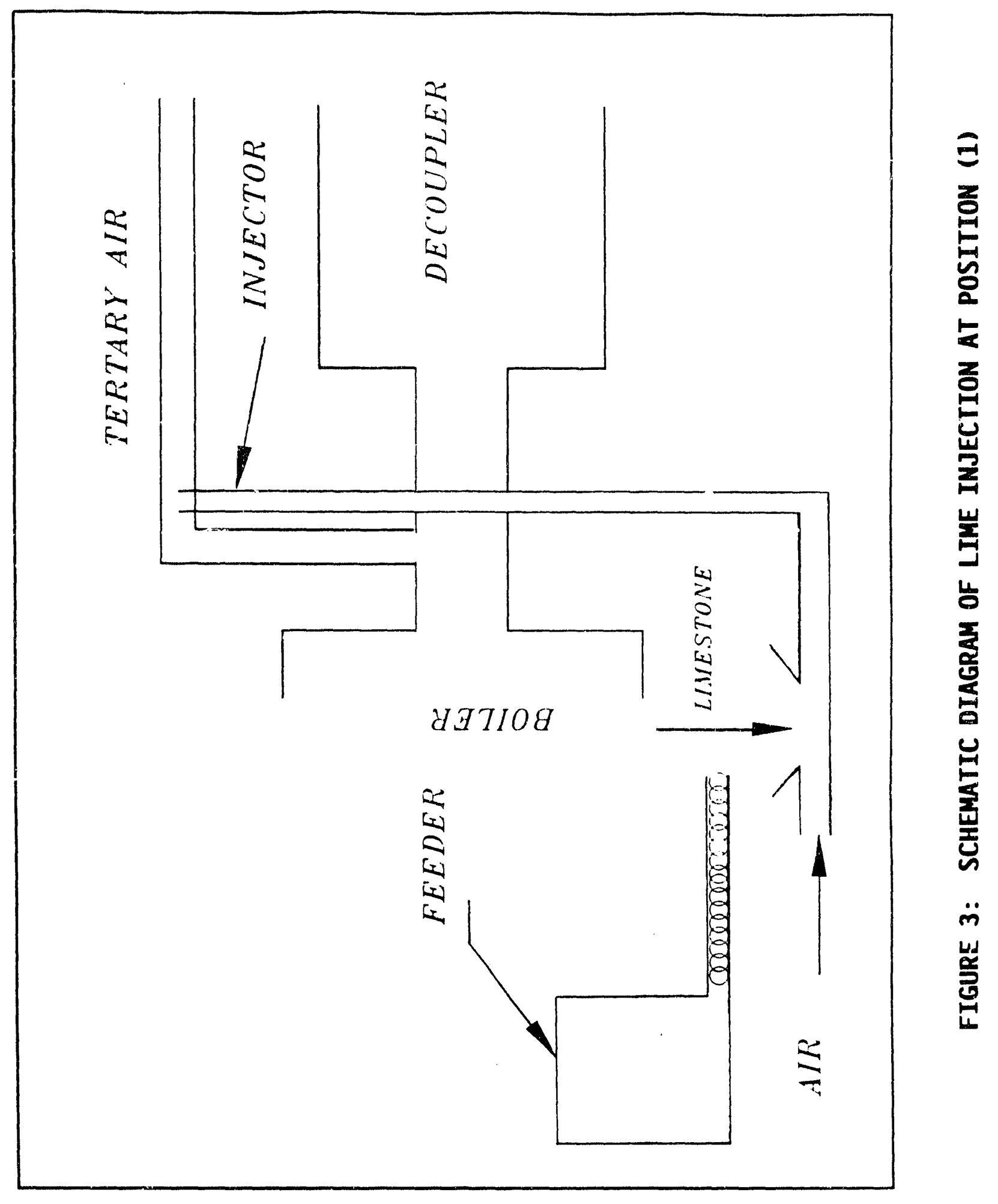


By injecting the limestone at this region, it would first heat up, calcine and then undergo sulfation reaction at lower temperatures in the fire-tube boiler.

Figure 4 shows the second position of limestone injection. The limestone could be injected directly anywhere along the length of the fire tube. Along the length of the fire tube, there is a temperature profile, where temperature at inlet to the tube is about $2200^{\circ} \mathrm{F}$ and at the exit $1200^{\circ} \mathrm{F}$. By injecting limestone at different locations along the fire tube, (i.e., at different temperature regions), the effect of temperature and residence time on sulfur reduction can be studied. The gas residence time at $4 \mathrm{MMBtu} / \mathrm{hr}$ firing rate from the inlet to the fire tube to the exit is approximately 0.7 seconds.

A shakedown test was conducted on May 20, 1989. The unit was initially heated on gas, then coal was introduced. The system operated as expected. The unit was shut down voluntarily. The operating history for this test is shown in Table 1. The proximate and ultimate ana?ysis of coal is shown in Table 2.

Test No. 2 was conducted on May 24, 1989. After two hours of testing on coal, the system reached equilibrium. At this stage limestone was introduced. Upon injection of limestone the $\mathrm{SO}_{2}$ concentration in the stack gas dropped from 1550 to $1100 \mathrm{ppm}$ with calcium/sulfur ratio of 3.0 . Also, the $\mathrm{NO}_{x}$ concentration dropped from 290 to $110 \mathrm{ppm}$ when limestone was injected. After 15 minutes of i imestone injection, a leak appeared between the tailpipe and bottom flange of the pulse combustor. The unit was shut down and inspected. Inspection showed that there was a weld failure at the connection between the tailpipe and the combustor. The unit was disassembled for repair.

Further tests on limestone injection will be conducted using a single combustor module or the full tandem $15 \mathrm{MMBtu} / \mathrm{hr}$ unit, which is under design. The limestone injection test matrix is shown in Table 3. 


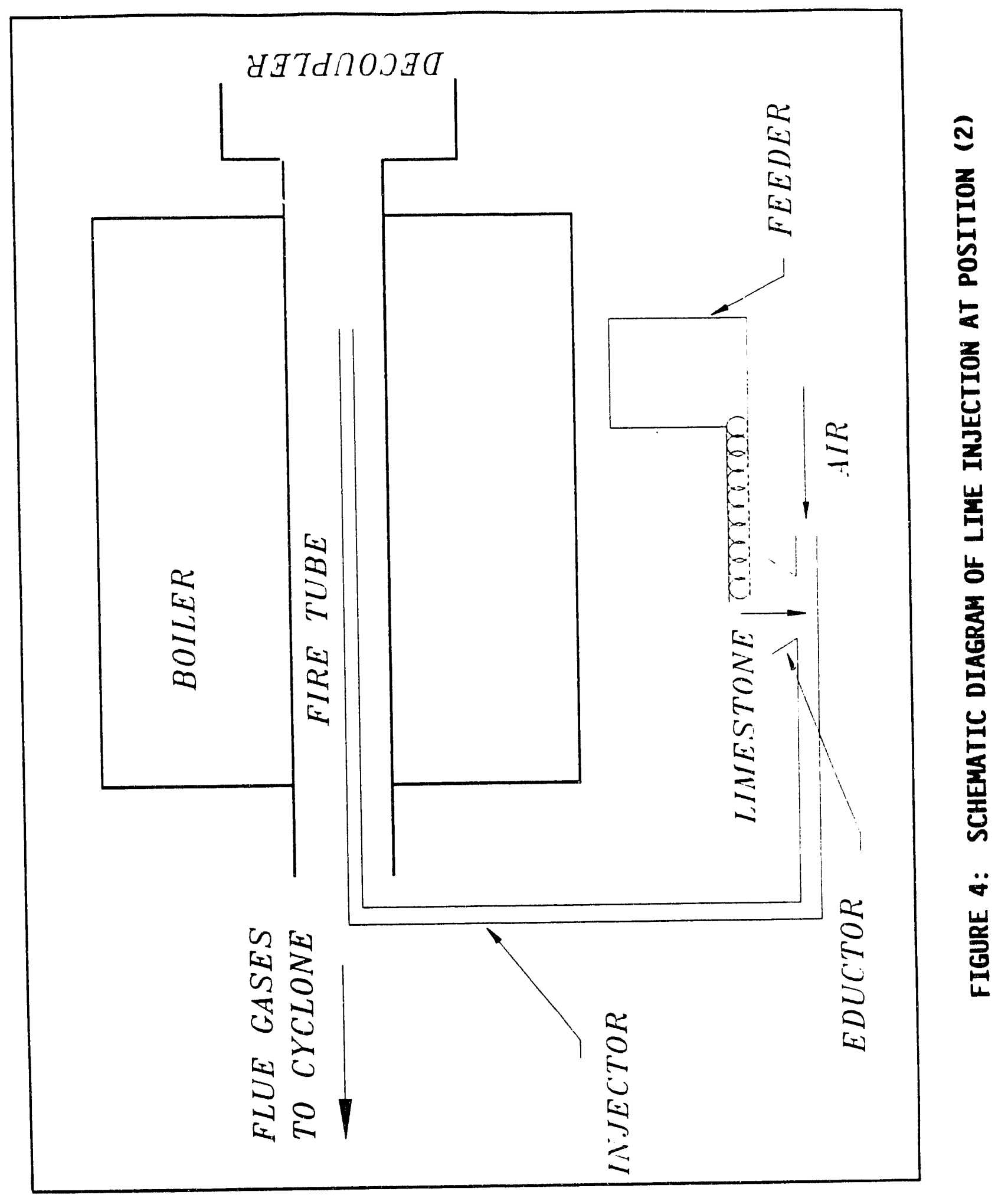




\section{Table 1. Shakedown Tests}

FEEDSTOCK:

FIRING RATE :

PULSATION PRESSURE:

CHAMBER TEMPERATURE:

DECOUPLER TEMPERATURE:

LIMESTONE INJECTION:

UTILIZED SORBENT:
DRY PULVERIZED COAL

4.3 MMBTU/HR (COMBUSTOR BEYOND DESIGN EXPECTATION

4-5 PSI

$>2800^{\circ} \mathrm{F}$

$>2700^{\circ} \mathrm{F}$

AT END OF DECOUPLER

AT CYCLONE/BY ISOKINETIC SAMPLING COLLECTION

Table 2: Proximate and Ultimate and Sulfur From AMALYSES FOR LOWER KITTANIng COAL

SAMPLE SOURCE

SAMPLE DATE

COAL ANALYSES, $W / W \%$ (MF)

Total Sulfur, as $\mathrm{S}$

Organic Sulfur, as $S$

Pyritic Sulfur, as $S$

Sulfate Sulfur, as $S$

Ash

Carbon Content, As C

Hydrogen Content, as $\mathrm{H}$

Nitrogen Content, As $\mathrm{N}$

oxygen Content, as 0

Chlorine Content, as $\mathrm{Cl}$

HEATING VALUE, BtU/Ib (MF)

MAJOR ELEMENTS IN ASH, W/W\%

Silica

$\mathrm{Al}_{2} \mathrm{O}_{3}$

$\mathrm{Fe}_{2} \mathrm{O}_{3}$

$\mathrm{TiO}_{2}$

$\mathrm{CaO}$

$\mathrm{MgO}$

$\mathrm{Ha}_{2} \mathrm{O}$

$\mathrm{K}_{2} \mathrm{O}$

Sulfites
$3 / 21 / 80$

5.34

2.21

3.13

0.00

12.58

71.55

4.91

1.05

4.57

0.15

13170

3409

19.61

40.03

1.33

1.01

0.46

0.38

1.37

1.40 


\section{Table 3: Sorbent Injection Test Matrix}

TEST NUMBER

$\mathrm{Ca} / \mathrm{S}$ (Molar Ratio

Recycle/Coal Ratio

LIMESTONE INJECTION LOCATION

Firing Load (MMBtu/hr)

Air Staging

Air Preheat Temperature $\left({ }^{\circ} \mathrm{F}\right)$
1

2.0

0.0

DECOUPLER

4.0

NO

100
2

2.0

2.0

DECOUPLER

4.0

NO

100
3 $\quad \underline{4}$

$3.0 \quad 3.0$

$3.0 \quad 3.0$

DECOUPLER DECOUPLER

4.0

NO

100

NOTE: These same tests will be repeated with the limestone injection in the fire tube to study temperature effects.

The pulse industrial tandem unit was disassembled for inspection due to a leak which was discovered between the tailpipe and the bottom flange of the pulse combustor during sulfur capture tests. Inspection showed that there was a weld failure at the connection between the tailpipe and the combustor. The failure seemed severe enough to warrant the fabrication of a new chamber and tailpipe. This failure was attributed to fatigue resulting from periodic start-up and shutdown. Further inspection revealed that $1 / 2$ inch of slag had coated the sides of the diverging section of the tailpipes. This coating decreased the volume of the tailpipes, thus affecting the tuning of the pulse combustors. A new design for the $7.5 \mathrm{MMBtu} / \mathrm{hr}$ single unit that is currently being developed will incorporate solutions to these problems.

\subsection{COAL-WATER SLURRY INJECTOR DESIGNS AND TEST (PhASE IA)}

Modifications were carried out on the coal-water slurry injector and atomizer in order to improve combustor performance. This consisted of attaching a dispersant medium (disc) to the tip of the atomizer to fan out the atomization pattern.

The previous tests were all conducted without this disc and the atomizer pattern was a long narrow spray as shown in Figure 5. 


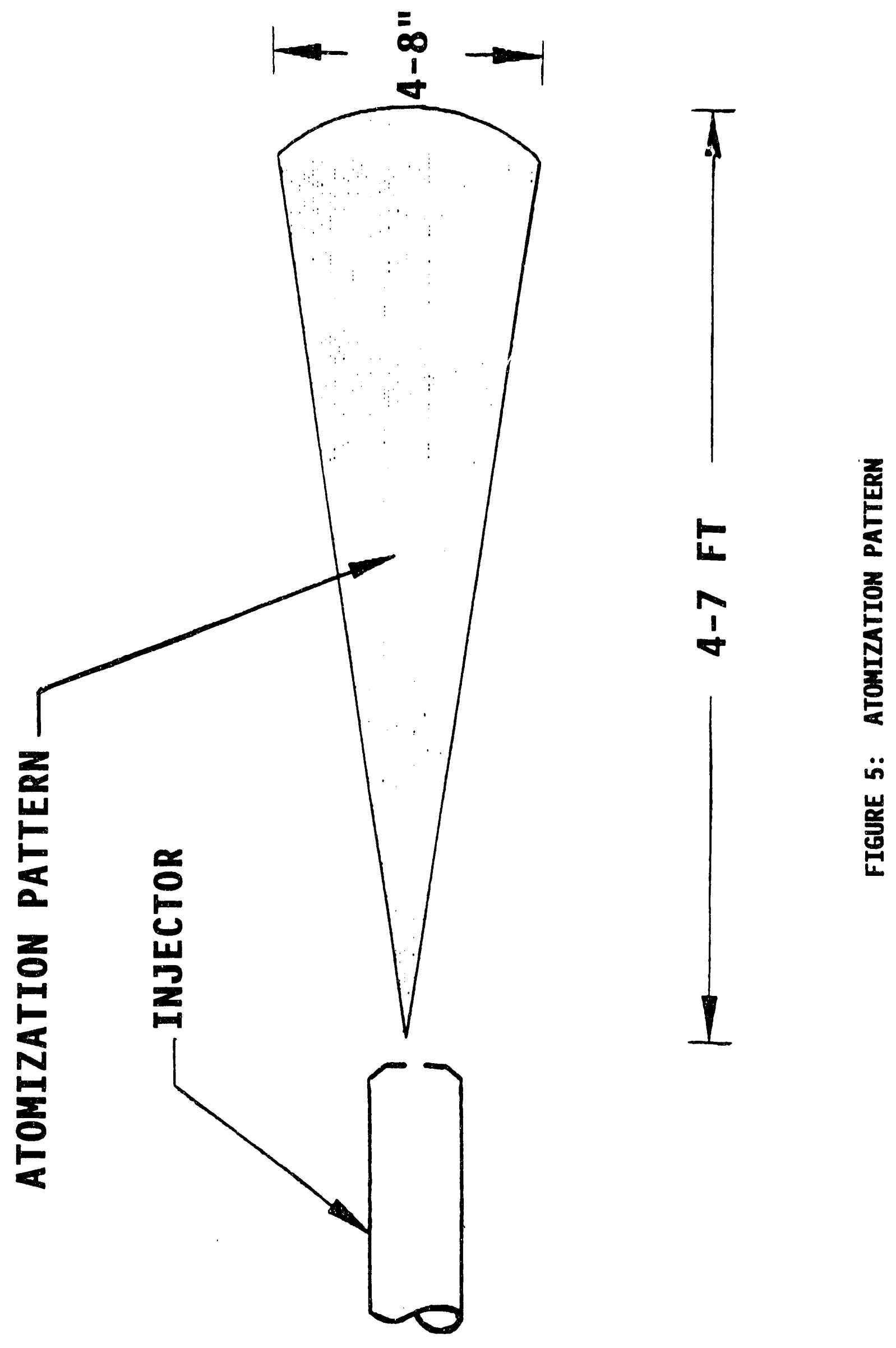


By attaching a disc of a specific size and geometry at a certain distance away from the atomizer tip, the atomization pattern can be changed considerably. The details are as follows: The various components of an injector tip assembly are identified in Figure 6.

Approximately 20 different tip arrangements were tested. Some of these are shown in Figure 7 . The tests can be classified into three phases.

Phase 1 - Consisting of $3 / 8$-inch swagelock nut with $1 / 2$-inch machine tool steel tips welded on the ends with various hole designs.

Phase 2 - Consists of a larger diameter spray nozzle with a $1 / 2$-inch swagelock nut and 3/4-inch machine tool steel tip.

Phase 3 - Returned to $3 / 8$-inch swagelock nut with multiple design "breaker" disc placed between $1 / 2$-inch and $11 / 4$-inch away from the hole in the associated tip.

Each evaluation is summarized by tip description, atomization results, spray pattern and form in relation to the combustion chamber and tailpipe assembly.

Two test mediums were used during the atomization experiments: 1) water and 2) coal-water slurry, to determine the performance of each tip. Since different tips respond differently to variation in air and liquid flow rates, standardized flows of 5 SCFM air and 5 lb per minute liquid rate were used.

Phase 1 - The first series of tests were performed utilizing a $1 / 4$-inch slurry tube with a Delavan spinner welded to the end surrounded by a 3/8-inch air tube.

\#1A: Used a straight beveled 1/2-inch machined disc with a $1 / 8$-inch hole drilled through its center; atomization was heavy and spray pattern too long, projecting approximately 6 feet down the tailpipe assembly.

\#1B: Used a curved beveled 1/2-inch machined disc with $1 / 8$-inch hole, to assist with air flow. Results were similar as in \#1A.

\#1C: Used a straight beveled 1/2-inch machined disc with 5 holes of $1 / 4$-inch diameter drilled in the center of the disc. Spray pattern was terrible with 5 straight streams of flow approximately 6-8 feet long. 


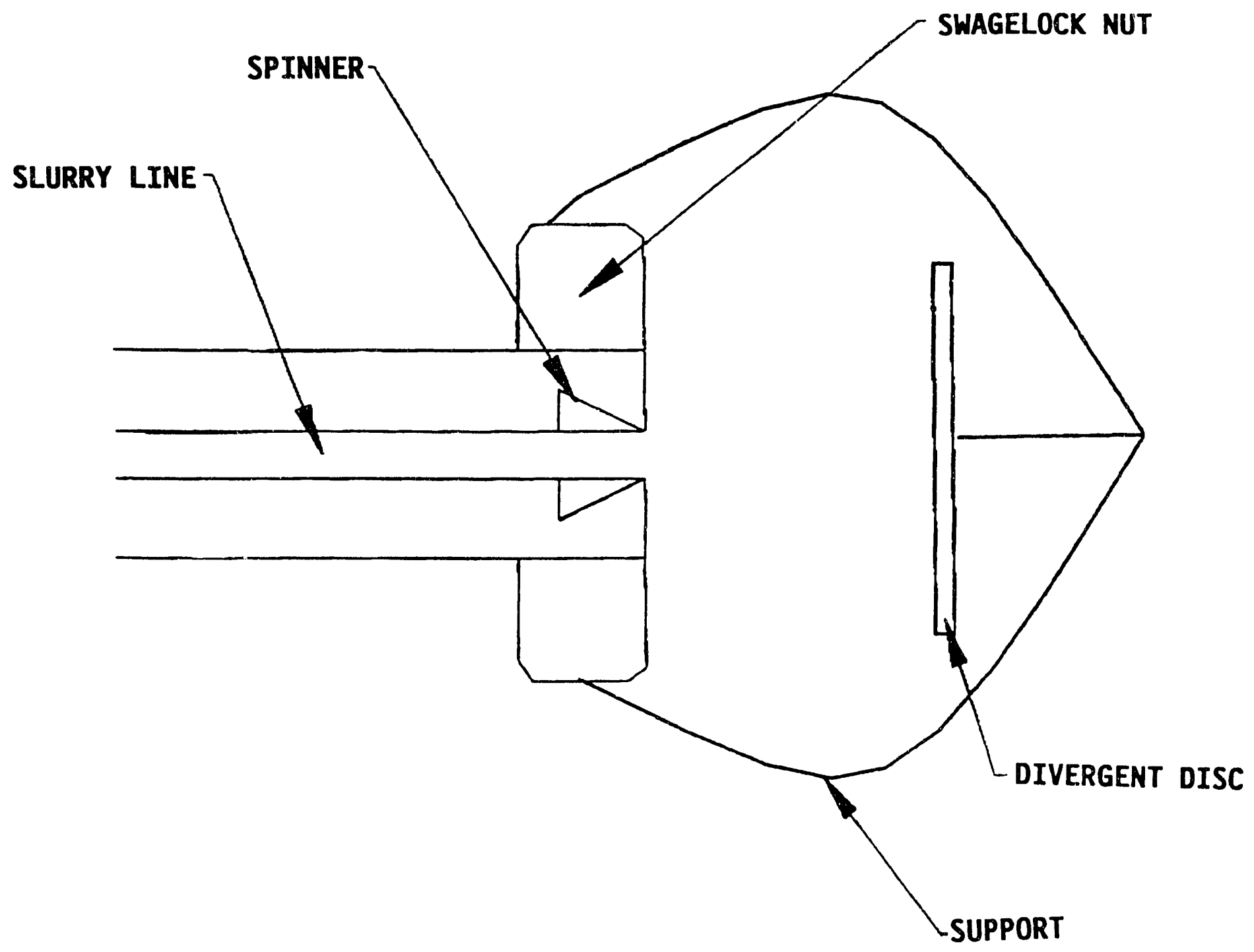

FIGURE 6: INJECTOR ASSEMBLY 


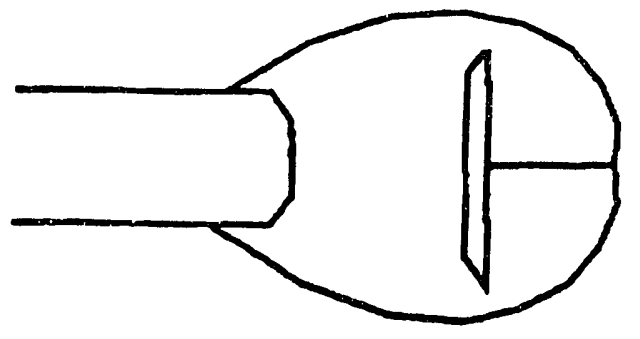

CONFIGURATION \$3A

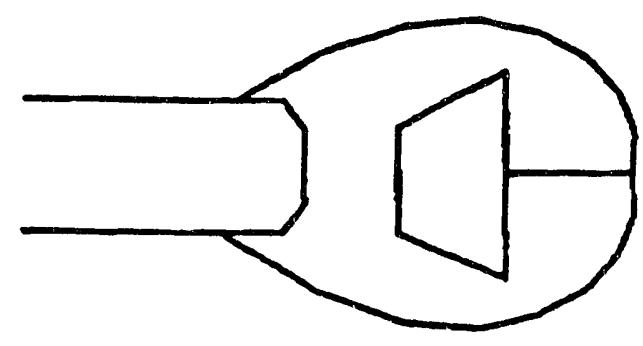

CONFIGURATION $\$ 3 E$

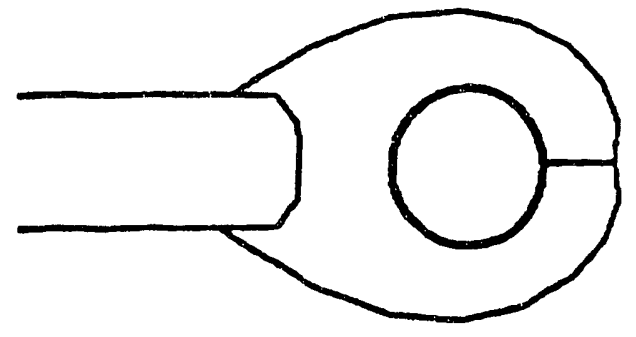

CONFIGURATION \#3D

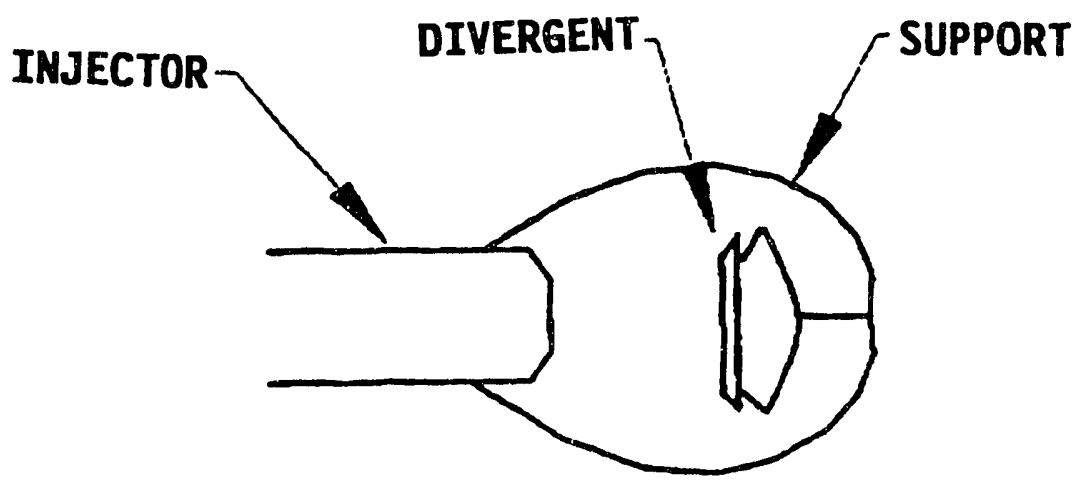

CONFIGURATION $\$ 3 C$

FIGURE 7: VARIOUS DIVERGING DISCS 
Phase 2 - Tests were conducted using a 3/8-inch slurry tube with $3 / 4$-inch air tube; no spinner was used, however spinner-like slits were cut into the $3 / 8$-inch tubing to give the spinner effect.

\#2A: Used a straight beveled 3/4-inch machined carbon steel tip with a 3/16-inch hole drilled through the center. This reduced the water velocity so that when air was added, the atomization was better than the \#1A design with a much shorter spray pattern and form.

\#2B: Used a convergent/divergent design similar to an educator; atomization was poor. Also, the idea is impractical due to considerable increase required in the height of the injector nozzle.

Phase 3 - Designs returned to the $1 / 4$-inch slurry tube with $3 / 8$-inch air tube and spinner nozzle. Using "breaker" discs placed between $1 / 2$-inch and 1 1/4-inch away from the exit of the tip to break up the flow. The idea here was to obstruct the flow in order to achieve secondary atomization.

\#3A: Utilized tip \#1C with a $7 / 16$-inch disc placed $1 / 2$-inch away from the end with a 1/8-inch hole drilled in the breaker disc. Atomization was poor and a very coarse spray was still streaming approximately 4 feet down to the tailpipe.

\#3B: Used previous tip \#1B with a $5 / 8$-inch half circle placed $3 / 4$-inch from end of tip. This breaker disc had 6 grooves filed into its surface to direct the flow. Atomization was reasonably go' $₫$ with a good pattern, however, the grooves tended to cause the medium to stream causing heavy droplets toward the outer edges of the spray.

\#3C: Utilized a mushroom design breaker disc; atomization was poor with poor spray pattern.

\#3D: Used a 5/8-inch $3045 S$ ball bearing placed 1 -inch away from tip \#1A. The front of the ball tended to break up the spray but the downstream end tended to regroup to produce poor atomization and pattern. Incorporating multiple dimples as in a golf ball produced negligible improvement. This same tip was then flattened on the font surface but again yielded poor results.

\#3E: Went to a cone design using tip \#1C; the atomization was good on water but poor and coarse on slurry. Pattern was good and projected approximately 2 feet into the combustion chamber.

\#3F: Used a similar cone design with stepped diameters to help break up the flow. No noticeable improvement was observed. 
\#3G: Used tip \#1B with a 1/2-inch curved disc similar to that used in test $\# 3 C$ with 2 discs placed on top of each other. Atomization was coarse with a decent pattern approximately 3 feet long.

\#3H: Again used tip \#13 with a mushroom design breaker disc. Atomization was better with a decent pattern.

\#3I: Used a flat 3/4-inch disc mounted $11 / 4$-inch away from tip \#1A; atomization and pattern were good, approximately 2 feet into the combustion chamber.

Conclusion: Upon completion of all the tests, the best attribute of each configuration was used to come up with the last and final design. The best pattern was seen in tip \#2A that being short and of fine structure and the best atomization was seen in tip \#3I. Therefore, a tip using a combination of these features was designed. This is termed tip \#4. It used a $1 / 2$-inch nut with 3/4-inch straight beveled disc and a 3/4-inch "breaker" diskette placed approximately $3 / 4$-inch away from tip end. Atomiza-tion was good with an excellent spray pattern and shape located approximately in the center of the combustion chamber. This tip gave the best overall atomization on slurry out of all those tested and shall be the one used in future combustor testing.

A test was conducted using the above atomizer tip \#4 in combustor $B$. Good pressure fluctuation (peak to peak) was observed with slurry firing but with an increase in slurry flow rate the combustor chamber plugged. Upon inspection of the chamber, the throat section was seen to be plugged. Since good atomization was achieved, it was concluded that a high droplet number density and a low evaporation/combustion rate precipitated the problem.

It was then decided to try multiple slurry injectors. Two injectors were mounted $180^{\circ}$ apart in combustor $B$ as shown in Fiqure 8 . An additional test was conducted and after three hours of testing on slurry and injection at the rate of $21 \mathrm{bm}$ per minute, the combustor once again plugged. The problem has been traced to long evaporation/combustion times for dense slurry droplet clouds. Changes in the combustor design are contemplated to increase the residence time. 


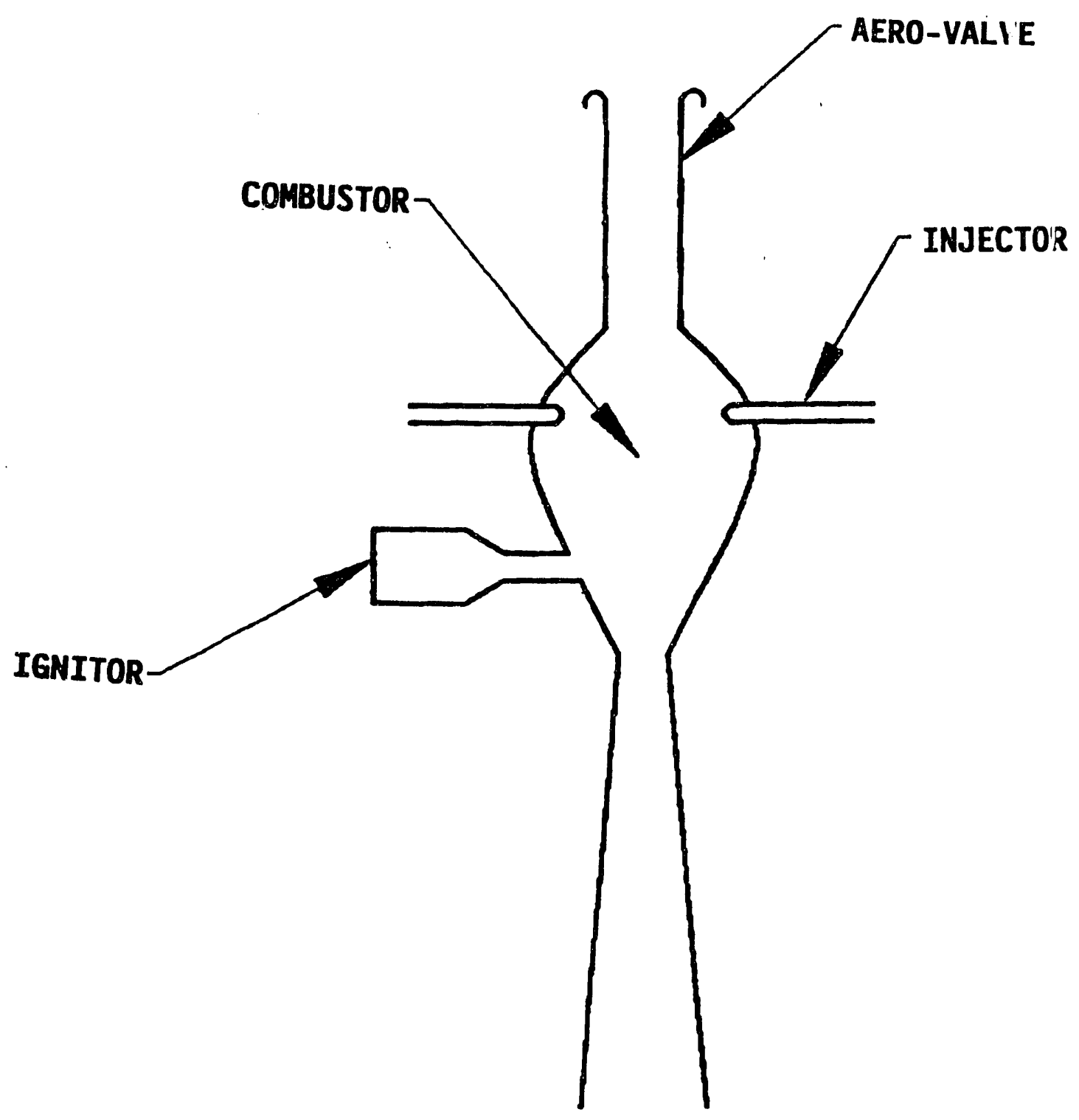

FIGURE 8: COMBUSTOR CONFIGURATION 


\section{SECTION 3.0}

\section{PLANNED ACTIVITY FOR THE NEXT PERIOD}

ine plans for the next period include completion of designs for the 7.5 MMBtu/hr unit, fabrication, installation, and system shakedown tests utilizing gas firing. A $750 \mathrm{KBtu}$ subscale test unit will also be fabricated to provide design verification and to generate experimental coefficients for the design code. It is also anticipated that this unit as well as the Phase IA integrated system will be used to test subsystem concepts, components, and operating procedures to resolve any issues or problems that can be anticipated with the pilot-scale unit. 

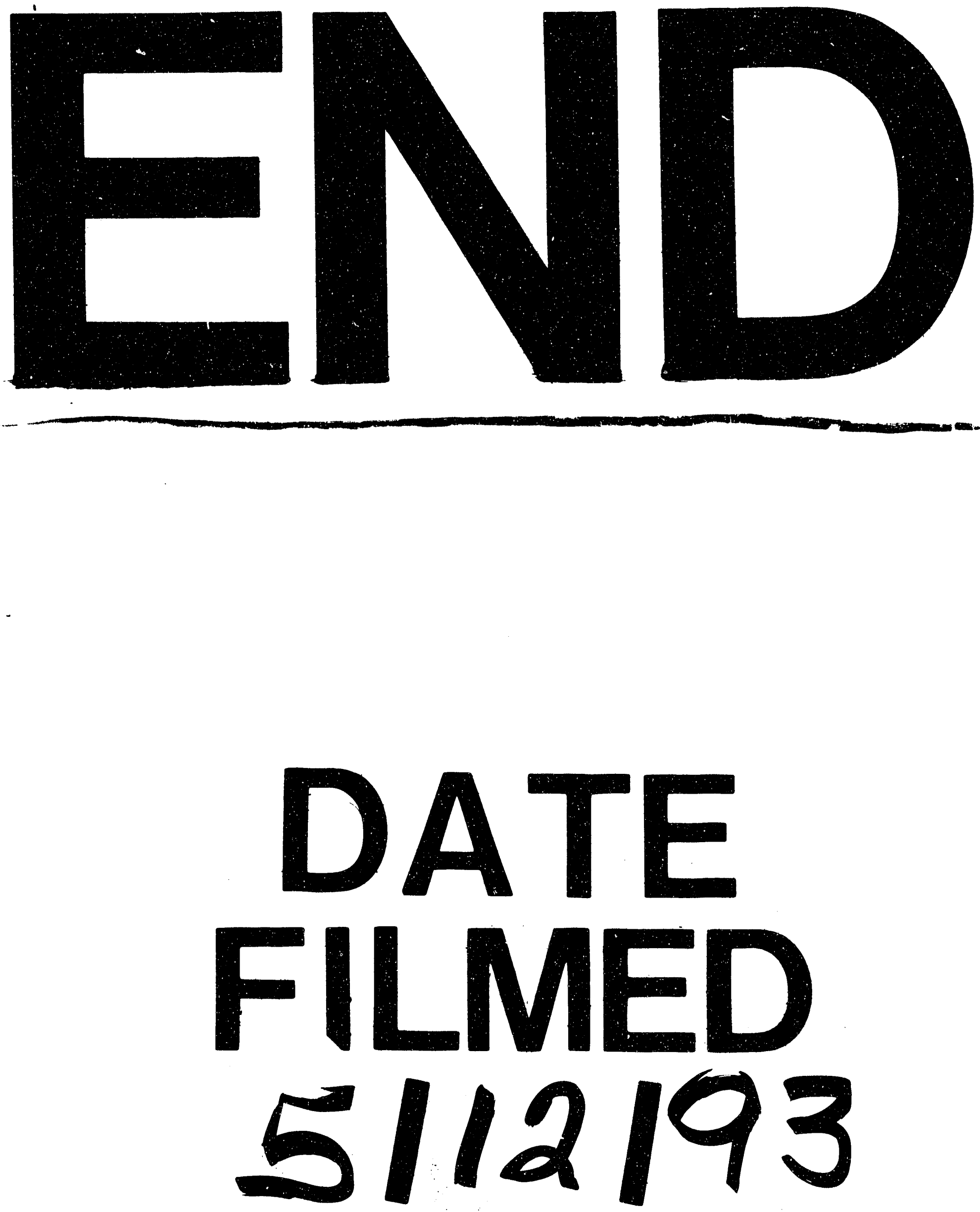